\title{
Dois professores
}

\section{J. Dalmo Belfort de Mattos}

Foi em março de 1931, que vimos pela primeira vez o Prof. Cardoso de Mello Neto.

Primeiro contáto com a vida academica. A sala 2 repleta de rapazes, á espera do "vestibular". Gritos confusos de veteranos, "troteando" calouros, por entre as arcadas do saguão. Um sól de outono pondo manchas de luz no soalho, três vezes centenário. As paredes de táipa da velha Faculdade, acolhendo mais uma turma de novos estudantes...

Estava quasi a findar a prova oral. Um nervosismo latente ameaçava explodir, turvando conceitos e idéias. . Faltava, entretanto, o exame de Hiștória. Onde deveriamos narrar o processo evolutivo da propaganda republicana, esmiuçar tramas da primeira Constituinte, do novo regimen.

Assunto que se prestava a discussões políticas, a agitar preferências, a desgostar o fundo afetivo do examinador.

Mal fitâmo-lo. E fomos desfiando, lentamente, os antecedentes do 15 de Novembro. Algumas perguntas aplainavam o caminho. E, embora divergindo por vezes, no exame das cáusas e efeitos, deixámo-nos cativar pela afabilidade do lente. E sentimo-nos quasi reconciliado com aquela Academia. Máu grado os bérros que vinham do pátio. E que presagiavam um "trote" a mais, para o "calouro", recemaprovado. .

Sete anos após, encontramo-nos de novo. Era ainda, um exame. O ambiente mudara. Sala "João Mendes". Be- 
cas cintadas de vermelho. Defesa de tese para livre-docência. E um nervosismo maior, a custo recalcado, e que apenas transparecia num vago sorriso. Quasi um "tic"...

Ainda uma vez, o Prof. Cardoso de Mello, como presidente da banca, foi o último a arguir. E o debate resvalou, como outróra, para o terreno das idéias jurídico-políticas. A História da segunda Constituinte republicana...

E, uma vez ainda, o tacto do arguidor deixou uma simpatia mais funda em nosso espírito.

Entre estas duas datas, porém, quanta mudança!

Foram, primeiro, as áulas de Economia Política, na velha sala 2. Fôra a análise imparcial e democrática das correntes e dos sistemas que, desde então, abalavam o mundo.

Foram as primeiras noções de Finanças. O estudo da moeda. A divergência com Macleod a concretizar sua estrutura e seu papel, na circulação da riqueza... 0 problema do crédito público e dos bancos de emissão...

Evitando a abstenção do liberalismo econômico, negando ao Estado a função de agente totalizador das energias. Fixando à atividade individual, o papel básico da produção das utilidades, o Prof. Cardoso de Mello ia-nos ensinando a evitar as soluções extremadas. E a conservar o justo meio termo, entre o "Estado-gendarme" dos individualistas e o "Estado-Providência" dos intervencionistas imoderados.

Depois, sobressaindo no ambiente conflagrado das Arcadas, foi o constituinte que se revelou a pugnar, na "Bancada Paulista", os verdadeiros rumos da nacionalidade...

Conhecíamos, então, o professor e o deputado. Anos após, era o administrador que se nos revelava, no govêrno do Estado. Procurando erguer inda mais alto o nome de S. Paulo. E aplicar, na realidade complexa dos fatos, os ensinamentos que difundira, ácerca da intromissão estatal na economia. 
E, meses depois, o interventor, tentando salvaguardar os nossos interesses. E defender, até o fim, a nossa projeção dentro e fóra do País...

$\mathrm{E}$, nesses longos meses de govêrno e de ação, em momentos particularmente difíceis, o Prof. Cardoso de Mello jamais separou o lente do homem público.

Parecia meditar nas palavras com que, em 1939, haveria de saudar o Professor de Ciências de Finanças da Universidade de Lisbôa:

"Nada mais apropriado para orientar governantes e governados no caminho... do que, entre outros, o conhecimento da disciplina que ensinais.

Nela confere-se ao administrador os meios de desenvolver a atividade do Estado, progressivamente crescente, pela soma de serviços que, a beneficio geral, lhe vão ficando a cargo.

Tudo, porém, dentro daquele ótimo meio termo, entre o dever do Estado de coordenar e dirigir, e o direito inalienavel da personalidade humana de pensar e agir por si".

Reinicia ele, mais tarde, seu magistério superior.

E então, decano do corpo docente, após 24 anos de atividade, assume a direção da Faculdade de Direito. E a Universidade expande, pela boca de seu Magnifico Reitor, o jubilo que este fato lhe cáusa:

"Nada vos falta para atingir ao apogeu da consagração. As demais passam com o tempo, e se somem com o tumultuar de paixões, mas, no cargo elevado a que acabais de subir, pelo vosso merecimento, permanecerá vossa ação sempre impressa, e para sempre, na alma, dos presentes e vindouros..." 
Nunca fomos discípulo do Prof. Spencer VAmpré. Tínhamos a guiar-nos, na síntese dificultosa da "Introdução à Ciência do Direito", a inteligência polimorfa do Prof. Dr. João ARruda. Que nos ambientava, aos poucos, na matéria.

Às vezes, porém, apareciamos mais cedo à Faculdade. $\mathrm{E}$ iamos assistir, das 9 às 10 horas, às preleções ministradas à segunda turma de calouros.

E o Prof. Vampré nos levava até a antiga Babilônia, onde o Código de Hammurabi consolidava a primeira legislação escrita. Dalí seguíamos à India. E, com Summer Marne punhamos em dúvida a antiguidade das leis de Manú e seus preceitos normativos...

O Prof. João Arruda dava-nos a visão panorâmica das Ciências do Direito, estudava o evolver das concepções, e a obra estruturante da técnica. O Prof. VAMPRÉ pendia mais para o estudo da "Enciclopédia Jurídica", para a pesquiza das origens históricas dos institutos.

E nós, - calouros ainda pouco à vontade com o carater universitário das disciplinas, enfeixavamos as duas preleções num esbôço. Por vezes desprovido de unidade sistemática. Mas que nos ia preparando para incursões futuras no cipoal de Filomusi-Guelfi. .

Encontrâmo-lo, depois, no curso prático de Latim, que ele mantinha, como introdução ao estudo do Direito Romano. E sob sua orientação, acompanhámos, de novo, o Cavalo de Tróia, através do 2. livro da Enêida. E revimos os textos cantantes de Vergílio...

E, com o correr do tempo, outras facetas de seu espírito se nos revelaram.

Era o jurista, que comentava os primeiros artigos do Código Civil.

Era o didata, a resumir, em súmulas perfeitas, o que havia de essencial na legislação vigente, em Direito de Familia, e em Direito das Coisas. 
Era o literato a evocar, nas festas de XI de Agosto, o "São Paulo de 1827", com suas vielas descendo no lançante das ladeiras, seus poetas e seus lentes universitários, boêmios e brigões, enchendo a Pauliceia com o rumor de antipatias burlescas...

Ele a evocava com o amôr de um ex-aluno pelo velho cláustro franciscano. Com o amôr que sempre revelara ao coligir-lhe as tradições e as narrativas, nas "Memórias para a História desta Faculdade".

E encerrava seus discursos citando a peroração de Lucio de Mendonça á gléba paulista:

“Terra sagrada de homens honrados, terra a que devo, mais do que o nascimento, a educação cívica; berço de minhas crenças, formosa terra de S. Paulo!"

Ainda uma vez nos encontramos, em 1938. Quando o Prof. VAMpré dirigia a nossa Faculdade, mantendo, com grande onus para os cofres públicos, o "Curso de Doutorado". Em que procurava desenvolver a cultura jurídica desinteressada. Mercê das pesquizas puras de Direito, longe da casuística forense e do tumultuar dos textos e das interpretações particulares.

E hoje, que a Faculdade tributa, nas paginas de seu órgão oficial, a homenagem sincera e merecida aos seus dois mestres - aqui deixamos consignada nossa admiração e respeito. Sentimentos que vêm de longe. Desde 1931.

Quando, ha onze anos passados, ingressavamos para o Curso de Bacharelado. E que vêm crescendo, com o tempo. À medida que os acontecimentos vão revelando, progressivamente, aos nossos olhos, seus conhecimentos e suas realizações... 